Артем Литовченко, Дмитрий Бойко

УДК 316.257(091)

Литовченко, А., Бойко, Д., Юрчик, Т. (2020). Ревизия социологического дискурса идеологии в дефинитивной перспективе. Социологические студии, 1 (16), 46-56.

DOI: https://doi.org/10.29038/2306-3971-2020-01-46-56

\title{
Ревизия социологического дискурса идеологии в дефинитивной перспективе
}

Артем Литовченко -

канд. сои. наук, доцент кафедры

политической социологии,

Харьковский национальный

университет имени

В. Н. Каразина, Харьков, Украина

Artem Lytovchenko -

PhD in Sociology, Associate Professor, Department of Political Sociology,

V. N. Karazin Kharkiv National

University, Kharkiv, Ukraine

E-mail: a.d.litovchenko@karazin.ua

ORCID: https://orcid.org/0000-0002-

$1439-5213$

\section{Дмитрий Бойко -}

канд. сои. наук, старший преподаватель кафедры политической соияиологии,

Харьковский национальный университет имени В. Н. Каразина, Харьков, Украина

Dmytro Boyko -

PhD in Sociology, Senior Lecturer,

Department of Political Sociology,

V. N. Karazin Kharkiv National

University, Kharkiv, Ukraine

E-mail: dmitry.n.boyko@gmail.com

ORCID: https://orcid.org/0000-0003-3425-

8555

Татьяна Юрчик -

студентка 2 курса сочиологического

факультета, Харьковский национальный

университет имени В. Н. Каразина,

Харьков, Украина

Tetyana Yurchyk -

second year student, School of Sociology,

V. N. Karazin Kharkiv National

University, Kharkiv, Ukraine

E-mail: xa12283262@student.karazin.ua

ORCID: https://orcid.org/0000-0002-9121-

3292

DOI: https://doi.org/10.29038/2306-3971-

2020-01-46-56
Социологический дискурс идеологии представлен многочисленными авторскими концепциями, в том числе и глубоко разработанными. Однако они разрознены и сами по себе не предоставляют универсального понимания и определения идеологии. Цель статьи - сформулировать непротиворечивую социологическую дефиницию идеологии на основе систематизации авторских подходов. Результаты обобщения наиболее значимых подходов воплощены в трёх условных блоках, выделенных по критерию представления о происхождении идеологии. Первый блок объединяет подходы, представляющие идеологию как результат целенаправленного конструирования. Второй блок - концепции, согласно которым идеология развивается естественным путём, вырастает из социальной ситуации и группового образа жизни. Третий блок представлен подходами, согласно которым происхождение идеологии двойственно и сочетает как естественно-социальные, так и искусственные элементы. Опираясь на проведенную систематизацию, мы определяем идеологию как единство суждений и практик, что закрепляет безальтернативность суждения и декларирует инвариантность практики; при этом суждения и практика взаимообусловлены. 
Reseived: April, 2020

$1^{\text {st }}$ Revision: April, 2020

Accepted: May, 2020
Ключевые слова: идеология, сознание, действительность, практика, систематизация, дефиниция.

Lytovchenko Artem, Boyko Dmytro, Yurchyk Tetyana. Revision of the Sociological Discourse of Ideology in a Definitive Perspective. The subject of the paper is sociological theorizing about the concept of «ideology». The results of this theorizing, which is represented by disparate author's approaches, are not systematized in modern sociology. Therefore, in sociology there is no universal theoretical basis and tools for the study of ideologies. As a result, ideology is pushed beyond sociological focus. We systematize the main sociological approaches to understanding ideology in order to formulate on their basis a universal sociological definition of ideology. We distinguish three conditional blocks of sociological approaches to understanding ideology according to the criterion of the origin of ideology. The first block is concepts in which ideology is presented as an artificial construct, purposefully used for political and managerial purposes. The second block is the concepts according to which ideology grows out of a group lifestyle as a living social phenomenon. The third block consists of approaches that combine both options to varying degrees. These approaches allow both the natural social emergence of ideology and its construction as an instrument of influence and control. The generalization and systematization of the approaches considered gives us the foundation for formulating the following definition of ideology. Ideology is the unity of judgments and practices, which reinforces the non-alternativeness of judgment and declares the invariance of practice; while judgment and practice are interdependent. We refuse to recognize the ideology as «false» or «wrong» about reality. We affirm that the distortion of reality by ideology is of the same nature as in any other form of social consciousness. It is due to the imperfection of the human senses, which give consciousness information about the material world. At the same time, ideology is twofold: as a reflection of reality, it is part of it, just as consciousness is part of reality. The dual nature of ideology makes sense the denial of ideology and actualizes criticism of ideology as revealing its disguised impact on the social order and processes.

Key words: ideology, consciousness, reality, practice, systematization, definition.

Литовченко Артем, Бойко Дмитро, Юрчик Тетяна. Ревізія соціологічного дискурсу ідеології в дефінітивній перспективі. Предмет статті - соціологічне теоретизування навколо поняття «ідеологія». Таке теоретизування представлено в соціології численними авторськими концепціями, проте навіть найдосконаліші 3 них не можуть надати універсального розуміння й визначення ідеології. Відсутня (принаймні у вітчизняній соціології) і змістовна систематизація цих підходів. Це нерідко призводить до витіснення цієї тематики за межі соціологічного дослідного поля. Мета статті - сформулювати несуперечливу соціологічну дефініцію ідеології на основі систематизації авторських підходів. Ми виокремлюємо три умовні блоки, до яких можуть бути вписані як розглянуті в статті найбільш масштабні соціологічні підходи, так і ті, що залишилися за межами розгляду. Критерієм для виділення блоків обрано уявлення про природу ідеології, про іiї походження. Отже, «штучний» блок об'єднує підходи, що представляють ідеологію результатом цілеспрямованого конструювання - це підходи Ф. Енгельса, К. Маннгейма, Д. Белла, С. Ліпсета, К. Гірца. Другий блок - це концепції, у яких уважається, що ідеологія виростає із соціальної ситуації, із групового способу життя; у нашій статті другої блок представлено концепціями Л. Альтюссера та С. Жижека. Третій блок складається з підходів, що різною мірою об'єднують обидва варіанти походження ідеології й допускають як їі природно-соціальне виникнення, так i конструювання або цілеспрямоване, інструментальне використання. До цього блоку ми зараховуємо підходи К. Маркса, А. Грамші, М. Хоркхаймера, Т. Адорно та Г. Маркузе. Узагальнення й систематизація зазначених підходів дали нам змогу визначити ідеологію як єдність суджень і практик, що закріплює безальтернативність судження та декларує інваріантність практики; при цьому судження й практика взаємообумовлені. Застосування цього визначення дасть змогу здійснювати не лише подальше теоретизування, а й проводити емпіричні дослідження ідеології на універсальній соціологічній основі.

Ключові слова: ідеологія, свідомість, дійсність, практика, систематизація, дефініція.

Мир един, аспекты его различны М. А. Лифшиц

Постановка научной проблемы, актуальность исследования. В девяностые годы ХХ в. не только для Украины, но и для других бывших советских республик тема политических идеологий казалась априори деактуализированной. Тем не менее, к этой теме, пусть и точечно, продолжали обращаться в научном дискурсе (достаточно вспомнить фундаментальную работу И. Поповой «Повседневные идеологии»). Социально-политические процессы в достаточной степени обострили 
проблематику идеологии и на уровне практик. Акции «Украина без Кучмы», неординарные результаты парламентских выборов 2002 г., наконец - президентские выборы 2004 г., вылившиеся в процессы т. н. Оранжевой революции, сопровождались (как минимум, на уровне деклараций) столкновением не всегда чётко сформулированных, но всё же легко видимых идеологем и идеологических позиций. Наконец, события 2013-2014 гг. - «Евромайдан», смена власти, гражданские беспорядки в юго-восточных областях, “отделение” Крыма и вооружённый конфликт на Донбассе максимально обострили идеологическую проблематику. Все конфликты и противостояния этого периода, а также последовавших за ним годов если не были идеологическими по своей природе, то имели и имеют идеологическую оболочку, влияющую на их протекание, итоги и восприятие обществом. Понимание украинских социально-политических процессов невозможно без понимания их идеологических аспектов, будь то процессы децентрализации, электоральная борьба или развёртывание конфликта на Донбассе. Украинское государство с 2014 г. резко усилило свою активность в идеологическом поле как на уровне контроля артикуляции идеологий в информационном, образовательном, культурном пространстве, так и на уровне межгосударственных взаимодействий.

Проблемная ситуация, таким образом, заключается в том, что состояние не только украинской политики, но и всего украинского общества в значительной мере определяется идеологическими процессами, противостояниями, конфликтами, расколами (см. Lytovchenko, Muradyan, 2014; Lytovchenko, Muradyan, 2018). Эта идеологическая составляющая или оболочка видима наблюдателю, она проявляется в дискурсе и в недискурсивных практиках (например, в акциях и систематической деятельности праворадикальных групп и организаций). При этом инструменты анализа и осмысления этих процессов у социологов либо отсутствуют, либо далеки и от совершенства и от обычной применимости. Причин тому множество: до 2014 г. идеологические мотивы и аргументы в отечественном политическом дискурсе всё ещё были «фигурами умолчания» - по инерции постсоветской традиции; в отечественном социологическом дискурсе инерция этой традиции оказалась ещё сильнее'; наконец, проблематику идеологий попросту выталкивали за пределы социологического дискурса как сугубо политологическую; один из соавторов этой статьи регулярно сталкивался с подобной позицией коллег-социологов на методологических семинарах и конференциях.

Итак, мы видим онтологический аспект проблемы в заметном усилении роли идеологической составляющей в социально-политических процессах, наблюдаемых в украинском обществе, при отсутствии полноценного социологического осмысления и объяснения этой составляющей. Это противоречие затрудняет прогнозирование и управление социально-политическими процессами, в том числе сужает функциональность политической социологии в познании этих процессов и в предоставлении консультаций государственным и общественно-политическим структурам и группам. Противоречие приобретает особую значимость, если принять во внимание, что социологам, а особенно политическим социологам, нередко приходится выступать в роли производителей идеологии или, как минимум, участвовать в таковом производстве в качестве одного из звеньев. Не важно, публикуем ли мы результаты опросов общественного мнения, выступаем в качестве экспертов в медиа или же читаем лекции студентам, - все эти ситуации являются ситуациями идеологического производства. И если роль идеологии в социально-политических процессах становится более значимой, её осмысление необходимо социологам хотя бы в рамках элементарной рефлексии.

Гносеологический аспект проблемы заключается в том, что сегодня социология идеологии представляет собой набор разных по качеству и несистематизированных концепций. В нем формально соседствуют фундаментальные разработки, например А. Грамши и Л. Альтюссера, и откровенно маргинальные творения Ф. Фукуямы или В.Кузнецова. Несмотря на относительно регулярные (правда, в основном в постсоветской, в частности российской социологии; социология западноевропейская и американская чаще рождает авторские подходы, трудно сводимые к единому

\footnotetext{
${ }^{1}$ Несколько парадоксальным образом маргинализация идеологической составляющей социально-политических процессов нередко осуществлялась за счёт близкого к вульгаризованному марксизму экономического детерминизма.
} 
знаменателю) попытки систематизации социологических взглядов на идеологию, сегодня социология, в т. ч. и политическая, не может предложить общий подход к пониманию и анализу идеологии. Наша статья - это шаг на пути к разработке такого подхода.

Цель статьи выведение непротиворечивой дефиниции идеологии на основании систематизации социологических подходов к её пониманию. Безусловно, достижение этой цели позволит решить проблему лишь в её гносеологическом измерении, и онтологический аспект будет предметом дальнейших публикаций.

Обзор исследований и степень разработанности проблемы. Явление идеологии попадало в поле зрения различных социологов и социальных учёных ${ }^{1}$, от К. Маркса, Ф. Энгельса и плеяды их идейных наследников до представителей противоположного по политической ангажированности лагеря, включая X. Арендт и 3. Бжезинского. Даже если ограничиться, помимо уже названных, именами лишь тех авторов, кто посвятил социологическому исследованию идеологий не одну работу, список получится внушительным: здесь и западные марксисты А. Грамши, Г. Лукач, А. Лефевр, Л. Альтюссер, и создатели неомарксизма Франкфуртской школы М. Хоркхаймер, Т. Адорно, Г. Маркузе, и представители социологии знания К. Маннгейм, П. Бергер, Т. Лукман, и сторонники «деидеологизационных» концепций Р. Арон, Д. Белл, С. Липсет, и исследователи культуры и дискурса (К. Гирц, Р. Барт, Т. А. ван Дейк), и трудно классифицируемые А. Этциони, А. Гоулднер, М. Буравой, И. Валлерстайн и Э. О. Райт. Список этот далеко не полон; а ведь в нём отсутствуют представители советской и постсоветской социологии, чьи исследования также нередко фокусировались на идеологии: В. Ядов, И. Попова, В. Танчер; современные отечественные социологи В. Бурлачук, П. Кутуев, В. Ищенко. Такое масштабное, на первый взгляд, социологическое внимание к идеологии, тем не менее, не снимает указанную выше проблему отсутствия общего подхода к пониманию идеологии.

Изложение основного материала и обоснование полученных результатов исследования. Понятие идеологии качественно эволюционировало, благодаря теоретическим разработкам К. Маркса и Ф. Энгельса, с приходом в науку, в том числе и становящуюся социологию, марксизма. К. Маркс, как замечает С. Жижек, утверждал: «они не понимают этого, однако все равно делают» (Жижек, 1999, с. 15). Мы лишь обратим ваше внимание на то, что оборот «ложное сознание», вопреки стереотипному мнению, принадлежит Ф. Энгельсу, а не К. Марксу. На данном этапе обоснуем принципиальный факт нетождественности видения и, как следствие, интерпретации явления идеологии К. Марксом и Ф.Энгельсом, несмотря на их творческий симбиоз. Именно Ф. Энгельс в письме Ф. Мерингу отождествляет идеологию с «ложным сознанием»: «Идеология это процесс, который выполняет так называемый мыслитель, хоть и с сознанием, однако с сознанием ложным» (Энгельс, 1966, с. 83). Ф. Энгельс практически первым в социологической теории заложил тенденцию к дифференциации сознания на истинное и ложное. Однако Ф. Энгельс не приводит читателю ни единого примера антипода «ложного сознания», сознания истинного; неопределенными остаются и критерии истинности; наконец, однозначность оценки сознания как истинного или ложного исподволь придаёт ему статичный, внесоциальный характер. В то же время идеология рассматривается учёным как процесс, который стимулируется определенными силами, которые с необходимостью остаются неизвестными для самого идеолога-творца (Энгельс, 1966, с. 83); если эти побуждающие силы очевидны для творца, то такой процесс не имеет отношения к идеологическому. Из этого следует вполне органичный вывод: если бы человек познал реальные (материальные) факторы, тогда идеологии однозначно «пришёл бы конец» (Маркс, Энгельс, 1961, с. 313-314). Взглянем на этот тезис с иного ракурса. Материальные факторы, о которых говорит Ф. Энгельс, уместнее рассматривать как главную проблему идеологии, лежащую в центре её структуры; когда

${ }^{1}$ Следует отметить, что вклад А. Дестюта де Траси, в отношении которого как «автора термина» совершается ритуальный реверанс практически каждым исследователем, пишущим об идеологии, отнюдь не ограничивается простым конструированием слова - достаточно вспомнить хотя бы придание идеологии научного характера и универсальных функций по отношению к иным нормопорождающим формам сознания. Однако при этом заслуживающая отдельного внимания концепция де Траси основана на логике долженствования, плохо применимой в социологических целях; по этой причине данная концепция и не включена в рассмотрение в рамках этой статьи. 
основная проблема идеологии становится явной (достигает настолько значительных масштабов, что её начинает замечать, распознавать большинство членов общества), с этого момента она будет восприниматься как независимая от идеологии, «реальная». В таком виде тезис Энгельса уводит нас от его концепции «ложного» сознания в сторону признания дистанции между идеологией и действительностью, но лишь в том же смысле, в котором дистанцирована от действительности любая форма сознания - в силу несовершенства органов чувств человека, обеспечивающих его контакт с внешним миром. Здесь уместнее использовать категорию искажения, а не ложности. Эта категория имеет большое значение для анализа сущности идеологии, и она понимается по-разному К. Марксом («Немецкая идеология») и Ф. Энгельсом (письмо Ф. Мерингу). Маркс утверждает, что индивиды как носители идеологии оказываются «перевернутыми» вверх ногами, как в камереобскура; применительно к идеологии он оперирует словом «иллюзия», тем самым подразумевая не «неправильность» отражения реальности идеологией, а несовпадение, «неточное» воспроизведение (Баллаев, 2004, с. 62).

Итак, К. Маркс считает, что идеологию следует рассматривать как специфическую форму сознания, основанную на иллюзии, но отнюдь не ложную. Ф. Энгельс, в свою очередь, закладывает традицию однозначной трактовки характерного для идеологии искажения действительности как ложного (читай - «вредного», «неудовлеторительного») (Энгельс, 1936). Маркс не «уличает» ни в чём идеологию как таковую; критикуя конкретную историческую разновидность немецкой идеологии, на категориальном уровне он лишь разводит иллюзию и реальность, подразумевая первую и производной, и частью последней. Во время обучения в Берлинском университете К. Маркс увлекался изучением оптики и строения глаза; отсюда и возникает объясняющая вышеназванный тезис иллюстрация: изображение чего-либо на сетчатке глаза обусловлено физиологическим строением глаз как части организма (Маркс, Энгельс, 1995, с. 25). В работах Маркса вырисовывается двойственное понимание идеологии: во-первых, как инструмента практического действия, принадлежащего правящему классу и использующегося с целью установления, поддержания власти; вовторых, как иллюзии, то есть специфической формы сознания, которая не может существовать вне реальности, так как содержит в себе образ реальности, который, в свою очередь, искажает её, но одновременно является и её частью.

Продолжение этой мысли можно встретить в «Тюремных тетрадях» А. Грамши (Грамши, 1991, c. 7), который разделяет идеологию на «низменную» (как инструмент правящего класса) и «возвышенную» (сознание, являющееся латентной составляющей экономики, права и т. д. ${ }^{1}$ ). Он утверждает, что индивид может действовать, при этом не осознавая собственных глубинных стимулов. Согласно Грамши, распространение идеологии детерминировано, в первую очередь, социальными факторами, а не политическими, что даёт достаточно оснований для использования его концепции в социологических целях (Грамши, 1991, с. 16). Определяющей целью идеологии, в понимании Грамши, является достижение симбиоза «низшего» и «высшего» классов. Учёный акцентирует внимание на том, что избавиться от «идеологических оков» можно исключительно в «низменном» значении. Он также указывает, что в научных кругах господствует разделение идеологии на «исторически-органическую» (как необходимую надстройку) и «придуманную» (как совокупность мнений отдельных индивидов) (Грамши, 1991, с. 53). А. Грамши полагает такую дихотомию весьма проблематичной, однако в глазах его современника и заочного оппонента К. Маннгейма оно вполне корректно.

К. Маннгейм предлагает разделять идеологию на частичную и тотальную. Тотальная определяется учёным как коллективное объективное мировоззрение, в структуре которого содержится истина (Мангейм, 1994, с. 56). Частичная идеология характеризуется как ситуативная, берущая своё начало во лжи, но при этом Маннгейм не указывает, чем ложь отличается от частичной идеологии (Мангейм, 1994, с. 55). Одновременно К. Маннгейм объясняет возникновение частичной идеологии тем, что отдельному социальному положению соответствуют свои конкретные мнения (Мангейм, 1994, с. 58). Мысль вполне очевидная; однако К. Маннгейм не объясняет, почему эти мнения он

\footnotetext{
1 Здесь можно усмотреть определённую связь с логикой А. Д. де Траси, укладывавшего идеологию, вернее - её предмет, ведь он полагал идеологию наукой - в основу морали, политики и культуры.
} 
трактует именно как идеологию, а не как ценности, идеи и нормы. Ничего не проясняет и постоянное употребление Маннгеймом оборота «объективная истина», которым учёный обозначает всеобщую приемлемость той или иной идеи, пытаясь тем самым социологизировать используемые философские категории. Но вместе с тем его понимание «объективной истины» ближе, скорее, к истине абсолютной. Однако абсолютная истина никак не связана с «общей приемлемостью», она не является результатом чего-либо, будь то познание или всеобщее одобрение, она - отражение существования. В процессе познания, возможно, мы можем получить доступ к истине абсолютной, но она при этом не является результатом этого процесса, не создаётся им. Всеобщая же приемлемость и значимость - это характеристики относительной истины; вот где корень той путаницы, которая неизбежно возникает при погружении в маннгеймовскую концепцию. Мыслитель ещё и усугубляет эту путаницу тем, что указывает: истина - это правильные точки зрения, доступные только определённому складу ума или определённой общности (Мангейм, 1994, с. 143). Что означает «правильные», как доступность той или иной общности свидетельствует об истинности идеи, - остаётся совершенно неясным; а упоминание критерия «демократически установленной общей значимости» как достаточного для определения истины и вовсе придаёт концепции Маннгейма скорее проповеднический, нежели научный пафос.

Активно критиковал концепцию К. Маннгейма в работе «Новая концепция идеологии?» М. Хоркхаймер, основатель Франкфуртской школы социальных исследований, неомарксист, работавший в рамках критической традиции. Он отмечает, что К. Маннгейм, фактически не скрывая, превратил учение о тотальной идеологии во всеобъясняющую теорию, сведенную к абсолютной истине, где последняя, в свою очередь, не получила широкого и аргументированного объяснения, вопреки её очевидной значимости для концепции. Декларируя свои марксистские позиции и при этом выступая как скрытый антимарксист, К. Маннгейм неумолимо пытается трансформировать философские дефиниции в социологические, но из-за работы преимущественно с понятиямиабсолютами (истинность, правильность, правдивость) успеха не достигает, оставаясь метафизиком (Horkheimer, 1930).

Т. Адорно, другой представитель Франкфуртской школы, не ограничился критикой предшественников, а предпринял попытку создания самостоятельной концепции идеологии. Он считал, что идеология легитимирует сам принцип мышления при помощи «предельной незаметности» (отсылка к Й. Фихте), всевозможными способами стремясь к самосохранению и превращению в Абсолют. Т. Адорно замечает, что для людей нет другого счастья, кроме как быть несвободными (чем не отличается от Г. Маркузе) (Адорно, 2011, с. 50). По мнению социолога, там, где субъект ощущает свою самобытность, он, напротив, представляется субъектом в меньшей степени, так как субъект является свободным лишь в той мере, в которой его свобода выгодна системе (Адорно, 2011, c. 339). Этот тезис в ёмкой форме описывает механизм действия идеологии, которая ограничивает, очерчивает контуры практической деятельности, придавая ей универсальные формы, применяемые большинством. Индивиды начинают действовать в соответствии с неким алгоритмом, тем самым «облегчая» своё существование в социуме.

Критика идеологии, по мнению Адорно, - это «критика самого конститутивного сознания» (Адорно, 2011, с. 193), рассуждение о роли субъекта и объекта, их динамике в идеологическом процессе, опровержение иллюзорной объективности. Идеология выступает в двух формах - как легитимное дополнение общественной жизни и как мираж всего, что существует будто бы неминуемо, обязательно. Идеология - это то, что «существует в самом общественном бытии» (Адорно, 2011, с. 459).

Г. Маркузе, прямой последователь Хоркхаймера и Адорно, считал, что идеология - это «необходимое условие продолжения функционирования» правящего общественного аппарата (ПОА) (Маркузе, 2003, с. 407); она выполняет функцию поддержания системы доминирующих ценностей (аппарата), а без нее эта система идей не сможет продолжить своё существование, по крайней мере, как правящая, и будет простой, уже бессистемной, совокупностью норм и ценностей (Маркузе, 2003, c. 70). Главная функция идеологии заключается в систематизации идей (в т. ч. в единый ПОА), обеспечении их монолитности и в выработке унифицированной модели практики. Идеология - это условие функционирования доминирующей системы ценностей и механизмов их воспроизводства. 
Г. Маркузе считает, что идеология воспроизводит подчинение и неравенство и, благодаря её непосредственному функционированию, остается заинтересованность и буржуазии, и пролетариата, вместе взятых, в сохранении существующего общественного порядка (Маркузе, 2003, с. 259). Люди не могут представить себе проживание за рамками установленной социальной структуры (Маркузе, 2003, с. 288), поскольку несвобода в практике является дли них обычной, то есть предопределённой заранее социальными институтами, которые воспроизводят устоявшийся порядок и ценности, а потому «безболезненной».

Таким образом, большинство франкфуртцев в рассмотрении идеологии опираются на сходную теоретическую концепцию несвободы практики индивидов, что во многом характерно для всего классического европейского теоретизирования об идеологии.

Свой ответ пристальному взгляду европейцев на идеологию предлагали американские учёные. Этот ответ тематически и хронологически совпал с парадигмальным кризисом середины ХХ в. в социологии. Так, Д. Белл является родоначальником концепции деидеологизации, которую он трактует как отход от ценностей (особенно отсутствие интереса к политической сфере), рассматриваемый на примере американской молодёжи (Bell, 1962, pp. 170-375). Конец идеологии - уменьшение значимости не только ценностной, но прежде всего эмоциональной составляющей современного общества, вследствие чего новейшие политические идеи не вызывают реакции «пристрастия или привязанности». На наш взгляд, Д. Белл, рассматривая идеологию как целенаправленно и искусственно сконструированный инструмент правящего класса, допускает неточность, не принимая во внимание идеологию как форму сознания. Объяснение сущности идеологии плотно связано с концепцией постиндустриального общества: по логике Белла, после отхода от традиционного уклада жизни, ориентированного в большей степени на ценности и нормы, которые конструировались именно высшим классом, в сторону постиндустриального, где все блага теперь являются всеобщей собственностью, потребность в существовании идеологии исчезает (Bell, 1962, pp. 20-23). Д. Белл рассматривал искажение, вызванное идеологией, как негативный факт (Белл, 2004, с. 371), наследуя (вряд ли осознанно), в первую очередь, Ф. Энгельса, во вторую - К. Маннгейма. Белл особое внимание уделяет тому, что наука должна быть внеидеологичной системой объяснений, (Белл, 2004, с. 511), однако игнорирует потенциальную идеологичность собственных суждений.

Другой американский ученый К. Гирц приходит к выводу, что сам термин «идеология» подвергся процессу идеологизации (Гирц, 2004, с. 226), однако избавление от обозначаемого им понятия - это вовсе не выход, потому как альтернативу в научном обороте найти практически невозможно. Гирц объясняет идеологическое мышление посредством сопоставления его с неясной системой символов и рассматривает саму сущность идеологии сквозь призму интересов (идеология как инструмент для получения желаемой власти) и напряжения (идеология как «симптом и лекарство»; индивид при помощи идеологии избавляется от тревоги). Не первым проводя демаркационную линию между наукой и идеологией, К. Гирц делает вывод, что эти две описанные категории отличаются степенью «заинтересованности»: наука проявляет тенденцию к сдержанности, а идеология - наоборот, гипетрофирует заинтересованность (Гирц, 2004, с. 260-261).

Его коллега и соотечественник С. Липсет рассматривал идеологию как механизм политической жизни, включающий четко поставленную цель и средства её достижения (Lipset, 1972). Ученый указывал: «демократическая социальная революция на Западе означает конец политической деятельности для тех интеллектуалов, которые вдохновились идеологическими и политическими мотивами» (цит. по: Гальцева, Роднянская, 2012, с. 11), подразумевая, что в силу сложившегося в мире консенсуса относительно разнообразных политических вопросов отбрасывается сама необходимость идеологии.

Противоположную деидеологизационным концепциям и стоящую особняком по отношению к европейской традиции исследования идеологии масштабную теорию идеологии предложил французский философ и социолог Л. Альтюссер. Он концептуализировал марксовскую модель базиса и надстройки, представив её в виде таких составляющих, как инфраструктура и суперструктура. Альтюссер разделил аппарат государства на два значимых компонента - репрессивный (правительство, администрация, тюремная/судебная система, армия, полиция) и идеологический (общественные институты - школы, телевидение, профсоюзы и т. д.). Оба компонента функцио- 
нируют, благодаря одновременно и насилию, и идеологии. Разница заключается в интенсивности: РАГ в большей степени использует насилие, ИАГ - идеологию. ИАГ выполняет функцию (вос)производства отношений и устоявшейся иерархии (Альтюссер, 2011). Л. Альтюссер сформулировал новаторский, даже с учётом марксовского фундамента, тезис о том, что практическая деятельность существует исключительно в форме идеологии: «благодаря идеологии, люди действуют самостоятельно, нет необходимости приставлять собственного полицейского следить за их задницами»; «нет практики, кроме той, которая совершается при помощи известной идеологии и под её руководством» (Althusser, 2014, p. 212). Не менее оригинальным ${ }^{1}$ стал и отказ Альтюссера от противопоставления науки и идеологии: согласно его концепции идеология выполняет сугубо практическую функцию, а наука - теоретическую («даёт нам знать»), и они дополняют друг друга, но отнюдь не противостоят. Учёный считал, что идеология - это воображаемое отношение индивидов к их реальным условиям существования (Althusser, 2014, p. 36), то есть искажения интерпретируется им как неизбежный эффект отражения, которое априори не претендует на полное воспроизведение оригинала.

Сходным путём идёт и С. Жижек, который категорически настроен против понимания идеологии как ложного сознания - наоборот, он уверен, что идеология - это не специфическое сознание, а «сама реальность» (Жижек, 1999, с. 14). Однако, с нашей точки зрения, ученый излишне радикально абсолютизирует и одновременно упрощает понимание идеологии и реальности, так как первое безосновательно становится универсальным объяснением и условием для всех социальных процессов, а понятие реальности сводится к актуальному на данный момент положению дел в обществе (Жижек, 1999, с. 28). С. Жижек отмечает, что в социальном мире идеология скрывает противоречие между её предложением и актуальными на тот момент обстоятельствами. Кроме того, исследователь полагает центральной задачей идеологии четкое направление движения и борьбы (Жижек, 1999, с. 46), которое влияет на другие составляющие данного процесса: когда мы снимаем маску идеологии, дабы увидеть истину, появляется лишь новая маска.

Обобщение и первичная классификация рассмотренных подходов позволяет выделить в их совокупности три условных (хронологически непоследовательных) блока по критерию природы или происхождения идеологии ${ }^{2}$. Этот критерий мы считаем фундаментальным, как минимум, потому, что от определения природы идеологии зависит итоговая оценка её социальной значимости и функций (например, авторы, полагающие идеологию искусственным конструктом, полагают, что от неё необходимо избавляться). Итак: 1) концепции, в которых идеология рассматривается как целенаправленно создаваемый (чаще всего с политико-управленческими и манипулятивными целями) конструкт; 2) концепции, утверждающие или подразумевающие «рождение», возникновение идеологии как естественно-социальный процесс, далёкий от сознательной воли конкретных личностей и групп; 3) концепции, так или иначе включающие оба варианта. Рассмотренные нами подходы распределяются в указанных блоках следующим образом ${ }^{3}$. В первый - «искусственный»блок попадают деидеологизационные концепции, принадлежащие Д. Беллу, С. Липсету, К. Гирцу, а также, отчасти, концепции Ф. Энгельса и К. Маннгейма. Энгельс, полагая идеологию «ложным» сознанием, придаёт ей инструментальный характер (не акцентируя внимание на двойственности её природы, в отличие от Маркса), а Маннгейм, применяя термин «идеология» к инструменту целенаправленного сокрытия действительного состояния общества (инструменту если и не искусственному, то, по крайней мере, искусственно изменённому), не распространяет его на непреднамеренно

\footnotetext{
1 Здесь так же, как и в концепции Грамши, можно усмотреть отсылку к теории де Траси, однако последний считал идеологию наукой, отождествлял их, тогда как у Альтюссера подобного отождествления нет.

2 Дихотомически этот критерий можно было бы сформулировать так: идеология либо создаётся, либо возникает; однако ряд подходов допускают оба варианта, поэтому дихотомия здесь недостаточно точна.

${ }^{3}$ Отметим, что сообразно формату статьи мы ограничили перечень рассматриваемых подходов наиболее масштабными и значимыми для нашей промежуточной в контексте полноценного социологического исследования идеологий цели. При насыщении этого перечня дополнительными подходами можно ожидать более богатый деталями, разнообразный итог; однако приводимую нами первичную классификацию это насыщение принципиально не изменило бы - как, впрочем, и конечный вывод статьи, представленный в авторском определении идеологии, приведённом ниже.
} 
(а лишь в силу социальной позиции носителей) искажающий действительность способ мышления, который предпочитает называть «утопией».

Второй, «естественно-социальный» блок представлен в нашей статье концепциями Л. Альтюссера и С. Жижека: для них идеология - это сама реальность и, вне зависимости от её использования в дальнейшем, возникает она естественно-социальным путём, вырастая из образа мысли и образа жизни социальных классов и групп, из практик (что позволяет Альтюссеру снять заложенное, в том числе ранними работами Маркса, противопоставление идеологии и науки). И, наконец, третий блок, объединяющий подходы, указывающие как на искусственные, так и на естественные «корни» идеологии, включает в себя подходы К. Маркса ${ }^{1}$, А. Грамши, М. Хоркхаймера (хотя его подход и является в большей степени критикой концепции Маннгейма, но в этой критике достаточно оснований для отнесения данного подхода именно к третьему блоку), Т. Адорно и Г. Маркузе.

Безусловно, при расширении перечня рассматриваемых подходов каждый из выделенных блоков пополнится новыми концепциями. Можно предварительно предположить, что в первый блок войдут подходы Э. Фромма, П. Бергера, Ф. Фукуямы, Р. Арона, З. Бжезинского, Э. Тоффлера, Э. Лакло и Ш. Муфф; во второй - варианты понимания идеологии, содержащиеся в работах Г. Лукача, В. Ленина, М. Лифшица, М. Фуко; в третий - концепции А. Лефевра, А. Зиновьева, Р. Барта, П. Бурдье, Н. Фэркло, Т. А. ван Дейк. Подобное расширение и дополнение - задача будущих исследований; на этом же этапе мы делаем вывод о том, что для формирования концепта, претендующего на универсальность в рамках социологического поля, логичнее опираться на концепции третьего блока - в немалой степени потому, что исследовательская логика этих концепций позволяет при необходимости использовать отдельные тезисы концепций первых двух блоков. Мы не можем пока однозначно оценить перспективы синтеза в сфере социологического теоретизирования об идеологии, однако, если таковые перспективы существуют, связаны они, несомненно, именно с третьим блоком.

Выводы и перспективы исследования. В качестве итога обобщения и систематизации подходов к пониманию идеологии предлагаем следующее определение. Идеология - это систем(атизирован)ное единство суждений и практик, которое закрепляет безальтернативность первых и декларирует инвариантность последних. Такое суждение является идеологически выдержанным, приемлемым, валидным, а практика - обязательной и «самоочевидной». Идеология может касаться любого сегмента (поля) социального пространства, а составляющие её практики и идеи имеют как искусственное (сконструированное), так и естественно-социальное (генетическое) происхождение. Наконец, идеология объединяет социально и позиционно разнородных агентов в рамках устойчивых отношений господства-подчинения, причем как в собственном идеологическом пространстве, так и за его пределами.

Такое определение позволяет не только вести дальнейшее теоретизирование, но и осуществлять эмпирическое исследование идеологии с социологических позиций. Среди наиболее отчётливых перспектив дальнейших исследований мы также можем назвать уже упоминавшееся насыщение трёхкомпонентной классификации идеологии, анализ функций идеологии, осуществление классификации идеологий по различным полям социального пространства, определение «(со)конструкторов» и «дизайнеров» идеологий; исследование механизма и инструментов действия идеологии. Всё это представляется вполне осуществимым при использовании предложенного нами определения, а также при условии принятия следующих тезисов $\left.{ }^{2}: 1\right)$ любая форма сознания искажает действительность в силу особенности функционирования сознания, которое не обладает ресурсами и инструментами для дублирования действительности (неискажённое воспроизведение действительности это и есть дублирование), и искажает действительность ещё на этапах ощущения и восприятия (как

${ }^{1}$ Мы считаем метафору сетчатки глаза и отпечатка реальности на ней достаточным свидетельством того, что Маркс, полагая идеологию «иллюзорной» формой сознания, признавал, как минимум, частичную «естественность» её происхождения.

2 Забегая вперёд, укажем, что в последующих исследованиях есть смысл особое внимание уделить теории отражения, в частности в версиях Г. Лукача и (особенно) М. Лифшица, поскольку, как минимум, первые три из нижеперечисленных тезисов исчерпывающе обосновываются её инструментарием; тщательно разбираемая Л. Альтюссером сложная взаимосвязь идеологии и действительности, несводимая к вопросам «первичностивторичности», полностью отражается в ёмкой формуле М. Лифшица, вынесенной в эпиграф этой статьи. 
минимум, в силу несовершенства человеческих органов чувств); 2) искажение не равноценно лжи и неправильности, а соотносится с действительностью так же, как относительная истина соотносится с абсолютной; 3) сознание и действительность не противопоставлены друг другу; хотя разводить их необходимо, разведение не отменяет взаимосвязи и взаимозависимости; 4) форма сознания, специфика которой обусловлена образом жизни конкретной группы или класса, может стать фундаментом или быть целенаправленно использована в качестве инструмента легитимации существующего или проективного социального порядка; исторически развившаяся социальная форма сознания может использоваться как инструмент правящего класса; 5) двойственная природа идеологии обессмысливает её критику как отрицание, но актуализирует критику как вскрытие неочевидных, замаскированных связей и механизмов.

\section{Источники и литература}

1. Адорно, Т. (2011). Негативная диалектика. Пер. с нем. Е. Петренко. Москва: Академический проект, $538 \mathrm{c}$.

2. Альтюссер, Л. (2011). Идеология и идеологические аппараты государства. Неприкосновенный запас, 3. Получено 30 ноября 2019 c https:/magazines.gorky.media/nz/2011/3/ideologiya-i-ideologicheskie-apparatygosudarstva.html

3. Баллаев, А. (2004). Читая Маркса: Историко-философские очерки. Москва: Праксис, 55-75.

4. Белл, Д. (2004). Грядущее постиндустриальное общество. Опыт социального прогнозирования. Москва: Academia, 788 с.

5. Гальцева, Р., Роднянская, И. (2012). Summa ideologiae: Торжество «ложного сознания» в новейшие времена. Критико-аналитическое обозрение западной мысли в свете мировых событий. Москва: Посев, 128 с.

6. Гирц, К. (2004). Интерпретация культур. Пер. с англ. О. Барсуковой, А. Борзунова. Москва: Российская политическая энциклопедия (РОССПЭН), 560 с.

7. Грамши, А. (1991). Тюремные тетради. Получено 17 ноября 2019 с https://www.civisbook.ru/files/ File/Gramshi,tetradi.pdf

8. Энгельс, Ф. (1936). Людвиг Фейербах и конец немецкой классической философии. Избранные про изведения. Получено 27 ноября 2019 c https://www.esperanto.mv.ru/Marksismo/Feuerbach/lfeuerbach.html

9. Энгельс, Ф. (1966). Письмо Франиу Мерингу в Берлин. Лондон. Получено 27 ноября 2019 с http://revarchiv.narod.ru/marxeng/tom39/eng_mering.html

10. Жижек, С. (1999). Возвышенный Объект Идеологии. Пер. с англ. В. Софронова. Москва: Изд-во «Художественный журнал», 114 с.

11. Мангейм, К. (1994). Идеология и утопия. Пер. с англ. М. Левиной. Москва: Юристъ, 7-276.

12. Маркс, К., Энгельс, Ф. (1961). Сочинения. Т. 21. Москва: Гос. изд-е полит. лит., 746 с.

13. Маркс, К., Энгельс, Ф. (1995). Немецкая идеология. Москва: Гос. изд-е полит. лит., 630 с.

14. Маркузе, Г. (2003). Эрос и ичивилизаичя. Одномерный человек. Исследование идеологии развитого индустриального общества. Пер. с англ. А. Юдиной. Москва, 526 с.

15. Althusser, L. (2014). On the reproduction of capitalism. Libcom. Retrieved November 30, 2019. https://libcom.org/files/louis-althusser-on-the-reproduction-of-capitalism.compressed.pdf

16. Bell, D. (1962). The End of Ideology. New York: Free Press, 501 p.

17. Horkheimer, M. (1930). Einneuer Ideologie begriff? Gleichsatz. Retrieved November 27, 2019 from https://www.gleichsatz.de/b-u-t/kriton/hork/horkheimer_mannheim.html

18. Lipset, S. (1972). Ideology and no end: The Controversy till now. Encounter. 39, 17-22.

19. Litovchenko, A., Muradyan, O. (2014). Preconditions for Regional Divisions in Ukraine and the Global Implications of the Ukrainian Crisis. In: Uluslararası Politikada Ukrayna Krizi. Istanbul: BETA. 590 p.

20. Lytovchenko, A., Muradyan, O. (2018). The destruction of political space: the case of Ukraine, 2014. Science and Education a New Dimension. Humanities and Social Sciences. VI(26), I.: 156, 104-107. http://seanewdim.com/uploads/3/4/5/1/34511564/hum_vi_156_26.pdf

\section{References}

1. Adorno, T. (2011). Negative dialectics. Transl. from German. E. Petrenko. Moscow: Academic Project, 538 p.

2. Althusser, L. (2011). Ideology and Ideological State Apparatuses. Neprikosnovennyi Zapas, 3. Retrieved November 30, 2019. https://magazines.gorky.media/nz/2011/3/ideologiya-i-ideologicheskie-apparaty-gosudarstva.html

3. Althusser, L. (2014). On the reproduction of capitalism. Libcom. Retrieved November 30, 2019 https://libcom.org/files/louis-althusser-on-the-reproduction-of-capitalism.compressed.pdf 
4. Ballaev, A. (2004). Reading Marx: Historical and Philosophical Essays. Moscow: Praxis, 55-75.

5. Bell, D. (1962). The End of Ideology. New York: Free Press, 501 p.

6. Bell, D. (2004). The Coming of Post-Industrial Society: A Venture in Social Forecasting Reissue Edition. Moscow: Academia, 788 p.

7. Engels, F. (1936). Ludwig Feuerbach and the end of German classical philosophy. Retrieved November 27 , 2019 from https://www.esperanto.mv.ru/Marksismo/Feuerbach/lfeuerbach.html

8. Engels, F. (1966). A letter to Franz Mehring in Berlin, London. Retrieved November 27, 2019 from http://revarchiv.narod.ru/marxeng/tom39/eng_mering.html

9. Galtseva, R., Rodnyanskaya, I. (2012). Summa ideologiae: The triumph of «false consciousness» in modern times. Critical and analytical review of Western thought in the light of world events. Moscow: Sowing, $128 \mathrm{p}$.

10. Geertz, C. (2004). The Interpretation of Cultures. Transl. from English. O. Barsukova, A. Borzunov. Moscow: Russian Political Encyclopedia, 560 p.

11. Gramsci, A. (1991). The Prison Notebooks. Retrieved November 17, 2019 from https://www.civisbook.ru/ files/File/Gramshi,tetradi.pdf

12. Horkheimer, M. (1930). Einneuer Ideologie begriff? Gleichsatz. Retrieved November 27, 2019 from https://www.gleichsatz.de/b-u-t/kriton/hork/horkheimer_mannheim.html

13. Lipset, S. (1972). Ideology and no end: The Controversy till now. Encounter, 39, 17-22.

14. Litovchenko, A., Muradyan, O. (2014). Preconditions for Regional Divisions in Ukraine and the Global Implications of the Ukrainian Crisis. In: Uluslararası Politikada Ukrayna Krizi. Istanbul: BETA. 590 p.

15. Lytovchenko, A., Muradyan, O. (2018). The destruction of political space: the case of Ukraine, 2014. Science and Education a New Dimension. Humanities and Social Sciences, VI(26), I.: 156, 104-107. http://seanewdim.com/uploads/3/4/5/1/34511564/hum_vi_156_26.pdf

16. Mannheim, K. (1994). Ideology and Utopia. Transl. from English. M. Levina. Moscow: Lawyer, 7-276.

17. Marcuse, G. (2003). Eros and civilization. One-dimensional person. A study of the ideology of a developed industrial society. Transl. from English. A. Yudina. Moscow, 526 p.

18. Marx, K., Engels, F. (1961). Works. (Vol. 21: Second Edition). Moscow: State publication of political literature, $746 \mathrm{p}$.

19. Marx, C., Engels, F. (1995). The German Ideology (T. 3: Second Edition). Moscow: State publication of political literature, $630 \mathrm{p}$.

20. Zizek, S. (1999). The Sublime Object of Ideology. Transl. from English. V. Sofronova. Moscow: Publishing House «Art Journal», 114 p. 